\title{
Proses Sandblasting dan Coating Pada Kapal di PT. Dok Perkapalan Surabaya
}

\author{
Wahyu Dwi Kurniawan ${ }^{1}$, Periyanto ${ }^{2}$ \\ 1,2 Jurusan Teknik Mesin, Universitas Negeri Surabaya \\ ${ }^{1}$ wahyukurniawan@unesa.ac.id \\ 2periyanto@mhs.unesa.ac.id
}

\begin{abstract}
Abstrak-Letak geografis Indonesia yang dominan dengan kepulauan maka bagian laut setiap daerah mempunyai kadar garam yang berbeda-beda dan akhirnya menyebabkan lambung dari kapal-kapal yang berlayar mudah terjadinya korosi atau kerusakan. Oleh sebab itu kapal-kapal yang berlayar harus sering untuk repair agar kapal yang digunakan untuk transportasi mampu bertahan lebih lama dari yang seharusnya terjadi karena faktor lingkungan alamnya, maka dari itu, untuk bagian lambung kapal yang terjadi kontak langsung terhadap air laut harus bisa dilindungi lebih dari bagian lain untuk melindungi bagian lambung diperlukan pengecatan dengan bermacam lapis jenis cat sesuai dengan fungsinya dan untuk menjadikan cat-cat tersebut mampu merekat dengan kuat terhadap permukaan dari lambung kapal maka harus menggunakan sandblasting untuk pembuatan profil pada permukaan logam lambung kapal atau bagian daerah lainnya. Keuntungan yang didapat dari proses sandblasting dan coating yaitu hasil repair yang didapat lebih maksimal dan berkualitas, dibandingkan hanya melakukan proses pengecatan secara biasa serta biaya yang mampu di minimaliskan agar tidak terjadinya pembengkakan karena proses yang terbuang sia-sia dan waktunya juga lebih efektif karena mampu diperhitungkan.
\end{abstract}

Kata Kunci-sandblasting, coating, lambung kapal, marine.

Abstract-Geographical location of Indonesia which is dominant with islands, so that the sea part of each region has different levels of salt and eventually causes the hulls of ships to sail easily to cause corrosion or damage. Therefore ships that sail must often repair so that the vessels used for transportation can last longer than they should because of natural environmental factors, therefore for the hull part of the ship that has direct contact with seawater must be protected more from other parts to protect the hull it is necessary to paint with various types of paint according to its function and to make these paints able to glue firmly to the surface of the hull, it must use sandblasting for profiling on the metal surface of the hull or other parts of the ship. The benefits of the sandblasting and coating process are the results of the obtained repair is more maximal and quality, than just doing the usual painting process and the costs that can be minimized so as not to cause swelling because the process is wasted and the time is also more effective because calculated.

Keywords - sandblasting, coating, ship hull, marine.

\section{Pendahuluan}

Secara astronomis wilayah Indonesia terbentang dari 6'LU-11'LS dan 95'BT-141'BT dan secara geografis berada di antara Samudera Hindia dan samudera Pasifik juga berada di antara benua Asia dan benua Australia. Ditinjau dari letak astronomis maupun letak geografisnya, banyak keuntungan yang dapat diperoleh dalam berbagai sektor. Sementara letak geografisnya menyebabkan Indonesia dilalui berbagai jalur pelayaran dunia karena menghubungkan jalur pelayaran antar dua benua besar. Sebagai negara maritim terbesar, sudah seharusnya sektor maritim memberikan keuntungan yang besar untuk perekonomian Indonesia. Indonesia saat ini telah melakukan banyak cara untuk mengembangkan pembangunan di bidang maritim, mulai dari pemodalan, pendukungan keuangan untuk industri perkapalan, pembebasan pajak import komponen kapal, pembangunan pelabuhan dan pengoptimalan galangan kapal, dan sebagainya sehingga memberikan peluang dan kesempatan yang baik bagi perusahaan galangan di Indonesia.

Dengan letak geografis Indonesia yang dominan dengan kepulauan maka bagian laut setiap daerah mempunyai kadar garam yang berbeda-beda dan akhirnya mebabkan lambung dari kapal-kapal yang berlayar mudah terjadinya korosi atau kerusakan. Oleh sebab itu kapal-kapal yang berlayar harus sering untuk repair agar kapal yang digunakan untuk transportasi mampu bertahan lebih lama dari yang seharusnya terjadi karena faktor lingkungan alamnya maka dari itu, untuk bagian lambung kapal yang terjadi kontak langsung terhadap air laut harus bisa dilindungi lebih dari bagian lain untuk melindungi bagian lambung diperlukan pengecatan dengan bermacam lapis jenis cat sesuai dengan fungsi nya dan untuk menjadikan cat-cat tersebut mampu merekat dengan kuat terhadap permukaan dari lambung kapal maka harus menggunakan sandblasting untuk pembuatan profil pada permukaan logam lambung kapal atau bagian daerah lainnya.

\section{TINJAUAN PUSTAKA}

\section{A. Kapal}

Kapal adalah kendaraan pengangkut penumpang dan barang di laut (sungai dsb) seperti halnya sampan atau perahu yang lebih kecil. Kapal biasanya cukup besar untuk membawa perahu kecil seperti sekoci. Sedangkan dalam istilah inggris, dipisahkan antara ship yang lebih besar dan boat yang lebih kecil. Secara kebiasaannya kapal dapat membawa perahu tetapi perahu tidak dapat membawa kapal. Ukuran sebenarnya di mana sebuah perahu disebut kapal selalu ditetapkan oleh undang-undang dan peraturan atau kebiasaan setempat. 


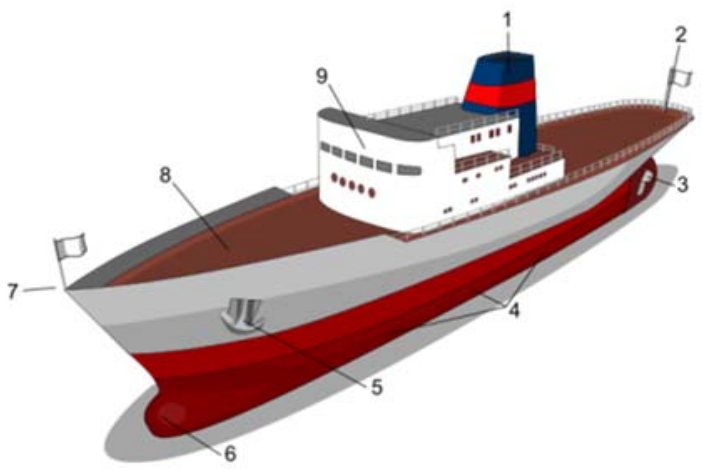

Gbr 1. Bagian-bagian kapal

Keterangan:

1).Cerobong, 2).Buritan, 3).propeler dan kemudi, 4).porside/Starboard, 5).Jangkar, 6).Bullbous Bow, 7).Haluan, 8).Geladak, 9).Anjungan.

Kapal sulit untuk diklasifikasikan, terutama karena banyak sekali kriteria yang menjadi dasar klasifikasi dalam sistem yang ada seperti [5]:

1. Berdasarkan Tenaga Penggerak Kapal tenaga manusia, kapal layar, kapal uap, kapal diesel/ motor.

2. Berdasarkan Jenis PelayarannyaKapal permukaan, kapal selam, kapal mengambang, kapal bantalan udara.

3. Berdasarkan Fungsinya, Kapal perang, kapal penumpang, kapal barang, kapal tanker, kapal feri, kapal tunda, tongkang, kapal keruk, kapal peti kemas.

\section{B. Lambung Kapal}

Lambung kapal (Inggris: hull) adalah badan dari perahu atau kapal. Lambung kapal menyediakan daya apung yang mencegah kapal dari tenggelam. Rancang bangun lambung kapal merupakan hal yang penting dalam membuat kapal karena akan memengaruhi stabilitas kapal, kecepatan rencana kapal, konsumsi bahan bakar, draft/kedalaman yang diperlukan dalam kaitannya dengan kolam pelabuhan yang akan disinggahi serta kedalaman alur pelayaran yang dilalui oleh kapal tersebut [5] .

1. Panjang Kapal

Panjang Kapal (Length) pada umumnya terdiri dari LOA (Length Over All), LWL (Length on designes Water Line), dan LBP (Length Beetwen Perpendicular):

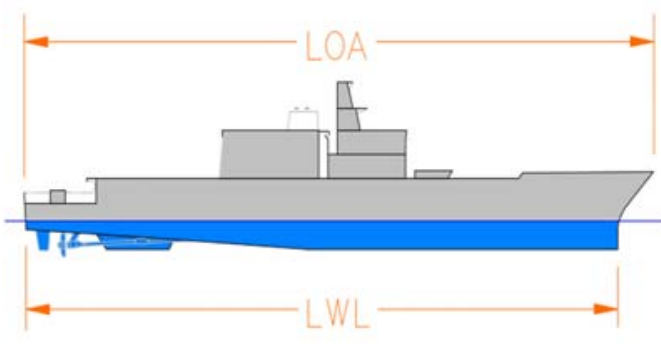

Gbr 2. 1 LOA dan LWL [4]

\section{a. LOA}

Secara definisi LOA adalah panjang kapal yang diukur dari haluan kapal terdepan sanpai buritan kapal paling belakang. Merupakan ukuran utama yang diperlukan dalam kaitannya dengan panjang dermaga, muatan, semakin panjang LOA semakin besar kapal berarti semakin besar daya angkut kapal tersebut.

b. LWL

LWL adalah panjang kapal yang diukur dari haluan kapal pada garis air sampai buritan kapal pada garis air laut.

c. LBP

LBP adalah panjang kapal yang diukur dari haluan kapal pada garis air sampai tinggi kemudi.

2. Lebar Kapal

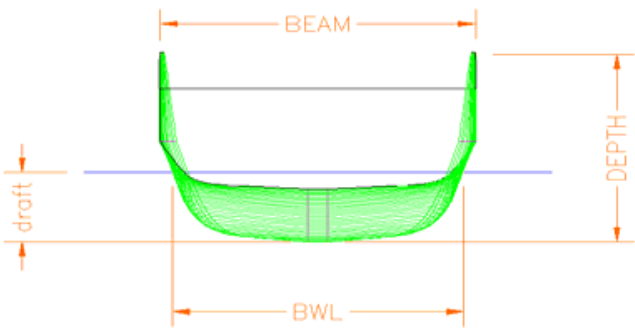

Gbr 3. BEAM, Draft, dan Depth.

Lebar dan kedalaman kapal merupakan ukuran utama lainnya dari kapal dalam menentukan ukuranukuran kapal. Ada beberapa ukuran lebar yang biasa digunakan dalam pengukuran dimensi lebar kapal yaitu Breadth Extrime dan Breadth Moulded.

a. Breadth Extrime

Lebar kapal Yang diukur dari kulit kapal bagian luar sampai kulit kapal bagian luar sisi lainnya (diukur pada bagian tengah kapal).

b. Breath Moulded

Lebar menurut mal ialah lebar yang diukur dari bagian luar gading-gading pada satu sisi ke gadinggading sisi yang lain. 
c. Sarat Air

Sarat air atau dikenal sebagai sebagai draft adalah jarak antara lunas sampai garis air, maksimumnya ditetapkan sampai batas lambung timbul.

d. Dalam (Depth)

Depth moulded (dalam) menurut mal adalah dalam yang diukur dari bagian atas lunas sampai bagian atas geladak.

3. Bentuk Lambung Kapal

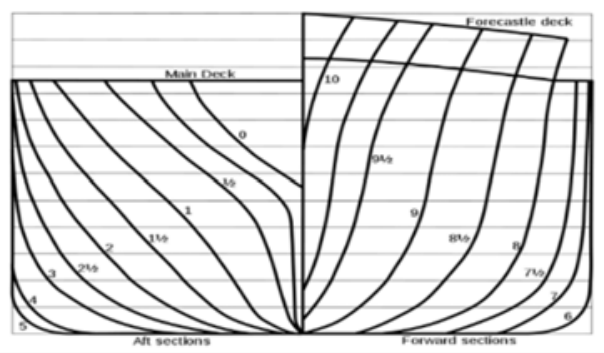

Gbr 4. Bentuk Lambung Kapal (hull shape)

Lambung kapal dapat berbentuk:

a. Bentuk V

Bentuk $\mathrm{V}$ atau dikenal sebagai $V$ shaped hull, merupakan bentuk lambung untuk kapalkapal dengan kecepatan tinggi atau untuk digunakan melalui laut yang ganas, seperti pada kapal perang.

b. Bentuk Bundar

Bentuk bundar atau dikenal sebagai round shaped hull.

c. Bentuk Datar

Bentuk datar atau dikenal sebagai flat bottom hull, merupakan bentuk lambung untuk kapal dengan kecepatan rendah dan volume angkut yang tinggi seperti pada kapal tangker.

\section{Pelapisan Logam}

Pelapisan logam adalah suatu cara yang dilakukan untuk memberikan sifat tertentu pada suatu permukaan benda kerja, dimana diharapkan benda tersebut akan mengalami perbaikan baik dalam hal struktur mikro maupun ketahanannya, dan tidak menutup kemungkinan pula terjadi perbaikan terhadap sifat fisiknya. Pelapisan logam merupakan bagian akhir dari proses produksi dari suatu produk. Proses tersebut dilakukan setelah benda kerja mencapai bentuk akhir atau setelah proses pengerjaan mesin serta penghalusan terhadap permukaan benda kerja yang dilakukan. Dengan demikian, proses pelapisan termasuk dalam kategori pekerjaan finishing atau sering juga disebut tahap penyelesaian dari suatu produksi benda kerja [2].

\section{Pengecatan Kapal}

Defenisi cat didalam standart ISO 4618-1 :

Cat adalah materi pelapis berpigmen dalam bentuk cair, pasta atau bubuk yang bila diaplikasikan diatas substrat akan membentuk lapisan film tak tembus cahaya dengan sifat teknis proteksi, dekorasi atau spesifikasi.

Varnish adalah materi pelapisan yang bila diaplikasikan diatas substrat akan membentuk lapisan film yang keras dan transparan dengan sifat teknis proteksi, dekorasi atau spesifik. Bagian-bagian cat diantarnaya yaitu : [8]

1. Resin

Menempel ke permukaan dan memberikan lapisan permanen. Varnish pelindung kayu terbuat dari resain, resin memberikan sebagian besar sifat cat:
a. Kekuatan
b. Adhesi/daya lekat
c. Tahan UV
d. Tahan solvent dan kimia

2. Pigment/extender

Pigment tidak larut, halus seperti bubuk. Dicampur kedalam cat untuk memberikan :

a. Warna

b. Daya tutup

c. Sifat anti korosi

d. Mengurangi permeabilitas

e. Sifat pengubah mis : spray dan gloss

f. Mengurangi biaya

3. Solvent

Merupakan campuran homogen zat yaitu campuran zat yang bagian-bagiannya tidak dapat dibedakan lagi. Perbedaan solute dan solvent yaitu zat terlarut sedangkan solvent zat pelarut.

4. Addittive

Digunakan dalam kuantitas kecil untuk merubah sifat seperti :
a. Waktu kering
b. Hold-up/daya lengket (tidak turun)
c. Setting (mengendap)
d. Meningkatkan penyebaran pigmen
e. Meningkatkan sifat mengalir setelah cat diaplikasi di permukaan

Pengecatan badan kapal berguna untuk melindungi kulit kapal dari proses pengkaratan dan juga binatang laut, karena hampir semua material penyusun kapal adalah logam (pelat baja) . Mengingat daerah kerja kapal adalah di laut maka sifat logam (pelat baja) reaktif terhadap korosi. Sebelum melakukan pengerjaan pengecatan terlebih dahulu material yang akan dicat harus bersih dari kotoran-kotoran minyak maupun sisa- sisa cat dan debu. Karena apabila 
dilakukan sandblasting membutuhkan biaya yang cukup mahal apalagi pengecatan harus dilakukan seperti bangunan baru, maka proses pembersihan dari kotoran tersebut harus benar- benar bersih. Sebelum mulai pengecatan maka kapal di bersihkan terlebih dahulu dengan tujuan menghilangkan kotoran-kotoran yang menempel pada kapal. Kapal sebagai alat transportasi air, maka dari itu sangat rentan terhadap kerusakan yang diakibatkan oleh air (korosi dan lapuk) maupun tumbuhan atau binatang laut yang menempel pada badan kapal yang tercelup air 8].

Korosi adalah peristiwa turunnya kemampuan material logam menerima beban, sebagai akibat terjadinya peristiwa oksidasi dengan lingkungan yang mengalami penipisan material dari konstruksi. Peristiwa korosi terjadi karena peristiwa alami ( Natural Process) reaksi elektro kimia, setiap logam yang memiliki laju korosinya masing-masing dan adanya lapisan pasif ( Passive Layer) pada permukaan logam tersebut. Korosi dapat diartikan juga sebagai lapisan - lapisan hasil reaksi dari logam terhadap lingkungan yang mengelilinginya. Dan korosi dapat dikelompokkan kedalam korosi basah dan korosi kering. Korosi basah disebabkan oleh karena lingkungan yang mengelilinginya mengandung larutan atau pelarut. Ini direfe rensikan pada sebagian besar kejadian korosi pada temperatur lingkungan. Pada sisi lain korosi kering dihasilkan oleh reaksi kimia dari gas dalam temperatur tinggi. Salah satu metode yang paling banyak digunakan dalam menanggulangi korosi, pelapukan, maupun binatang dan tumbuhan laut yang terbukti efektif adalah pengecatan (protective coatings). Komponen utama dalam pengecatan ini yaitu cat. Cat merupakan suatu bahan cair atau bahan kental yang terdiri dari hantaran medium (vehicle) yang merupakan bahan cair dari bahan cat itu sendiri. Bahan pewarna dan bahan penunjang (partikel yang kecil dan tidak larut dengan hantaran medium), ditambah dengan beberapa bahan tambahan dalam jumlah tertentu, sesuai campuran dan takarannya [8].

Pencampuran berbagai jenis bahan baku dengan jumlah dan proporsi tertentu menjadi satu kesatuan, dengan pengawasan laboratorium produksi yang ketat dari tahap awal hingga menghasilkan produk cat yang siap pakai.

Untuk mendapatkan hasil pengecatan yang baik dan berkualitas maka pihak yang terkait dalam pengecatan perlu mengetahui dasar - dasar pengecatan baik teknis aplikasi maupun pengawasan sehingga perlakuan dan penanganan dapat dilakukan sedemikian rupa untuk memenuhi spesifikasi baik oleh aplikator pemilik inspektor atau konsultan sehingga selama proses pengecatan diharapkan dapat meningkatkan hasil kerja dan kualitas secara efisien [8

Perlindungan pelat dari korosi dapat dilaksanakan dengan pengecatan, dimana pengecatan sesuai peraturan - peraturan pengecatan untuk kapal. Sebelum diadakan pengecatan, persiapan memegang peranan penting terhadap hasil pengecatan. Pelat yang akan dicat harus bersih dari karat - karat, minyak, dan kotoran akibat oksidasi lainnya dan sebelum pengecatan harus sesuai rencana kegiatan (painting schudule) baik cara pengecatan maupun waktu pengeringan yang dibutuhkan, terutama yang harus diperhatikan adalah pada tempat- tempat pengelasan dan bekas-bekas pekerjaan yang mengandung minyak/graise [8].

Pelaksanaan pengecatan dapat dilakukan dengan menggunakan roll, kuas, ataupun menggunakan semprot. Macam - macam cat yang digunakan untuk mengecat kapal adalah: [8].

a. Untuk badan kapal bagian bawah ( keel) sampai denganbottomdigunakan cat anticorrosion (AC). Cat AC berguna untuk melindungi badan kapal daripengkaratan.

b. Selanjutnya diadakan pengecatan dengan cat anti- fouling (AF) untuk mencegah menempelnya hewan dan tumbuhan laut.

\section{E. Sandblasting dan Coating}

\section{Sanblasting}

Musuh abadi seluruh benda berbahan dasar metal/besi adalah karat/korosi. Ada salah satu cara yang paling efektif dan cepat untuk mengusir karat/korosi yaitu sandblasting. Sandblasting, adalah proses penyemprotan abrasive material biasanya berupa pasir silika atau steel grit dengan tekanan tinggi pada suatu permukaan dengan tujuan untuk menghilangkan material kontaminasi seperti karat, cat, garam, oli dll. Selain itu juga bertujuan untuk membuat profile (kekasaran) pada permukaan metal agar dapat tercapai tingkat perekatan yang baik antara permukaan metal dengan bahan pelindung misalnya cat.

Tingkat kekasarannya dapat disesuaikan dengan ukuran pasirnya serta tekanannya. Perlu diketahui berhasil atau gagalnya suatu pengecatan sangat tergantung pada tingkat kebersihan dan tingkat perekatan antara cat dan permukaan serta tingkat kepadatan dan perataan dari cat itu sendiri. Sandblasting merupakan proses yang diadaptasi dari teknologi yang biasa digunakan oleh perusahaan-perusahaan yang bergerak dibidang oil \& gas, industri, ataupun fabrikasi guna membersihkan atau mengupas lapisan yang menutupi sebuah obyek yang biasanya berbahan dasar metal/besi dengan bantuan butiran pasir khusus yang ditembakkan langsung dari sebuah kompresor bertekanan tinggi ke obyek. 
Sandblasting terbagi atas 2 jenis, yaitu :

a. Dry Sandblasting

Dry Sandblasting biasa diaplikasikan ke bendabenda berbahan metal/besi yang tidak beresiko terbakar, seperti tiang-tiang pancang, bodi dan rangka mobil, bodi kapal laut, dan lain-lain.

b. Wet Sandblasting

Wet Sandblasting diaplikasikan ke benda-benda berbahan metal/besi yang beresiko terbakar atau terletak di daerah yang beresiko terjadi kebakaran, seperti tangki bahan bakar, kilang minyak (offshore), ataupun pom bensin, dimana pasir silica yang digunakan dicampur dengan bahan kimia khusus anti karat yang berguna untuk meminimalisir percikan api saat proses sandblasting terjadi.

Namun begitu, alat yang digunakan tetaplah sama, terdiri dari kompresor, tabung penyaring udara (Airblast Breathing Air Filters), tabung penampung pasir (blast pot), selang, nosel, helm khusus untuk dikenakan oleh sang operator sandblasting [8)].

c. Keuntungan dari Sandblasting :

1) Membersihkan permukaan material (besi) dari kontaminasi seperti karat, tanah, minyak, cat, garam dan lainnya.

2) Mengupas cat lama yang sudah rusak atau pudar

3) Membuat profile (kekasaran) pada permukaan metal sehingga cat lebih melekat.

d. Mengukur tingkat kebersihan sandblasting :

Ukuran standar sandblasting adalah Sa 2.5. Sa adalah salah satu standard tingkat kebersihan yang dikeluarkan oleh Swedish Institute for Standards disingkat SIS. Kode Sa disini berarti standard kebersihan Swedish menggunakan Abrasive.

Pengertian Sa.2.5 berarti pembersihan/ penyemprotan metal menghampiri putih "near-white metal blast cleaning", dengan pengertian bahwa penyemprotan terhadap permukaan metal dilakukan sampai warnanya hampir putih. Secara kasat mata, warnanya mendekati putih, bersih dari segala kotoran seperti kulit besi, karat, bekas cat, debu, dan sebagainya, yang tertinggal hanya sedikit noda atau bintik kecil yang samar dan itupun tidak boleh lebih dari $5 \%$ dari total suatu permukaan yang dibersihkan. Untuk dapat mengetahui secara pasti bahwa tingkat kebersihan yang dikehendaki telah tercapai, dipakai acuan warna sebagai perbandingan berupa referensi warna permukaan disebut dengan visual pictorial surface standard. Sedangkan yang menggunakan alat dengan magnifier "surface profile comparator" gunanya untuk melihat tingkat kekasaran permukaan setelah sandblasting [8].

Standard-standard yang lain selain Swedish Standard yang digunakan untuk tingkat pembersihan permukaan ada beberapa, misalnya standard dari SSPC (Steel Structure Painting Council), NACE (National Association of Corrosion Engineers), ISO (International Organization for Standarization), SAA (Standard Australia), DS (Standard Denmark) dan JUS (Standard Jugoslavia), tetapi yang sangat umum digunakan saat ini adalah Standard Swedish, SSPC, dan NACE [8].

2. Coating/painting

Di Indonesia Marine Coating memiliki sebutan nama tersendiri untuk membedakan dengan jenis cat lain. Para nelayan biasanya menyebut marine coating dengan sebutan cat marine atau cat kapal, cat marine termasuk jenis cat kapal yang berkelas dan berkualitas, karena cat kapal ini di fungsikan untuk melindungi bagian kapal agar terhindar dari korosi dalam jangka waktu yang cukup lama. Sifat proteksi pada cat kapal sangat diutamakan mengingat kapal terus menerus berhadapan dengan air laut yang mengandung garam yang sangat tinggi $(\mathrm{NaCl})$, disamping itu cat kapal sendiri juga berhadapan langsungdengan cuaca yang tiada hentihentinya, yaitu hujan, panas dan dingin. Kombinasi resin dan pigment serta additive dalam material cat kapal mempunyai sifat atau karakteristik yang sangat baik.

Bagian kapal besi yang perlu perhatian khusus adalah under water atau bawah air laut, karena bagian ini merupakan bagian kapal yang selalu terendam kedalam air, apalagi air yang dihadapi adalah air laut, dimana air laut ini mengandung kadar garam laut $(\mathrm{NaCl})$ yang sangat tinggi, sehingga mudah sekali terjadi korosi.

Proses pengecatannya pun terdiri dari 3 lapisan diantaranya: Primer coat, Intermediate coat dan finish coat. Proses pengecatan kapal besi pada bagian yang terendam air setelah proses blasting, dianjurkan menggunakan Primer Coat yang mempunyai ketahanan anti korosi yang sangat baik, primer coat ini hendaknya mempunyai pigment yang berbasis zinc pigment, dimana zinc pigment ini dapat mencegah besi terkorosi, baik oleh air maupun air laut [8].

Proses pengecatan kapal besi pada bagian yang terendam air setelah pengecatan primer coat, dianjurkan menggunakan Intermediate coat, Intermediate Coat ini disamping berfungsi sebagai pelindung lambung kapal agar supaya tidak teresap air laut langsung, juga berfungsi sebagai penebal cat.

Proses pengecatan kapal besi pada bagian yang terendam air setelah pengecatan Intermediate coat, dianjurkan menggunakan Anti Fouling, cat anti fouling ini berfungsi sebagai pelindung lambung kapal bagian bawah yang terendam air laut agar supaya tidak 
ditumbuhi lumut dan tertempelnya binatang laut. Seperti tiram, kerang dan lainnya.

Pada pengecatan kapal besi untuk bagian yang tidak terendam air laut langsung, tetapi kadang kala bersentuhan dengan air laut, pada bagian ini biasanya kita sebut sebagai bagian boot top. Pengecatan pada Boot top terdiri dari 3 lapisan, diantaranya Primer Coat, Intermediate Coat dan Finish Coat

Proses pengecatan kapal besi pada bagian boot top setelah proses blasting, dianjurkan menggunakan Primer Coat yang mempunyai ketahanan anti korosi yang sangat baik, primer coat ini hendaknya mempunyai pigment yang berbasis zinc pigment, dimana zinc pigment ini dapat mencegah besi terkorosi, baik oleh air maupun air laut.

Proses pengecatan kapal besi pada bagian yang Boot top setelah pengecatan primer coat, dianjurkan menggunakan Intermediate coat, Intermediate Coat ini disamping berfungsi sebagai pelindung lambung kapal agar tidak mudah korosi, juga berfungsi sebagai penebal cat.

Proses pengecatan kapal besi pada bagian Boot top setelah pengecatan Intermediate coat, dianjurkan menggunakan Finish Coat yang berfungsi sebagai pelindung lambung kapal bagian atas (boottop). Finish Coat ini berfungsi sebagai decorative paint yang mempunyai agen sebagai anti weathering (anti cuaca) juga berfungsi sebagai anti gores atau gesekan. Finish caot ini mempunyai ketahanan usia hingga 5 tahun lebih. Pada pengecatan kapal besi untuk bagian top side, cat primer coat dianjurkan yang mempunyai basis resin dan pigment yang tahan terhadap korosi dan cuaca. karena akan berhadapan langsung dengan matahari dan hujan. Sinar ultraviolet serta air hujan yang mengandung asam serta basa dapat mengakibatkan kapal besi mudah terkorosi [Windyadari Aulia, FZ.Ahmad,Sarwoko. (2014)].

Pada pengecatan Finich coat kapal besi untuk bagian top side, dianjurakan material cat yang mempunyai dua fungsi, diantaranya fungsi sebagai Decorative dan fungsi sebagai Protective. Pada fungsi decorative finish coat untuk top side hendaknya ada pilihan warna sesuai dengan permintaan customer, sedang pada fungsi protective finish coat mempunyai ketahanan terhadap sinar ultraviolet matahari dan cuaca air hujan.

Pada pengecatan kapal besi untuk bagian ruang mesin (engine rooom) dianjurkan menngunakan material cat yang tahan terhadap minyak, air, dan panas temperatur ruangan. Proses pengecatan pada engine room mempunyai dua lapisan yaitu Primer coat dan Finish coat.

Pada pengecatan kapal besi untuk bagian ruang mesin (engine rooom) dianjurkan menggunakan primer coat yang mempunyai resin dan pigment yang dapat mencegah korosi.

Pada pengecatan kapal besi untuk bagian ruang mesin (engine rooom) Finish coat yang dianjurkan adalah yang mempunyai pilihan warna, akan tetapi sebaiknya menggunakan cat yang berbasis pigment alumunium atau silver.

Deck Side atau Deck Paint, pada pengecatan sebuah kapal besi untuk bagian lantai dasar atau yang terinjak oleh kaki, dianjurkan menggunakan cat yang mempunyai ketahanan terhadap goresan atau injakan kaki sehingga cat tidak mudah mengelupas ataupun abrasi. Cat Deck Paint mempunyai triple fungsi, yaitu Decorative (terdapat pilihan warna), Protective (dapat mencegah karat, abrasive dan weathering) dan Securitive (tidak mudah slip apabila diinjak oleh telapak kaki). Proses pengecatan Deck Paint terdiri dari 2 lapisan yaitu Primer Coat dan Finish Coat.

Primer Coat pada pengecatan sebuah kapal besi untuk bagian lantai dasar atau yang terinjak oleh kaki atau biasa disebut deck paint, dianjurkan menggunakan Primer Coat yang mempunyai ketahanan terhadap korosi air laut dan cuaca.

Finish coat untuk Deck Side atau Deck Paint, pada pengecatan sebuah kapal besi untuk bagian lantai dasar atau yang terinjak oleh kaki, dianjurkan menggunakan cat yang mempunyai tidak mudah slip, dapat mencegah korosi serta mempunyai ketahanan cuaca. Bagian peralatan kapal yang tidak kalah penting dan urgent yang juga butuh untuk perawatan adalah jangkar dan rantai. Jangkar dan rantai kapal ini dianjurkan dicat agar supaya tidak korosi dan bertahan cukup awet. Sehingga dianjurkan menggunakan cat yang long oil alkyd yang juga sering disebut cat bituminous [8].

\section{METODE}

Metode dalam kegiatan ini diantaranya yaitu:

A. Observasi,

Secara langsung mengamati bagaimana proses dan cara pengecatan yang dilakukan para pekerja di Dok Apung Surabaya IV dan ponton baru, khususnya pada KM. tekun Jaya serta ponton $1,2,4$, dan 5 .

B. Wawancara,

Mewawancarai karyawan baik dari pihak PT. Dok Dan Perkapalan Surabaya (Persero) dan pekerja subkontraktor tentang segala sesuatu yang berkaitan dengan proyek tersebut.

C. Literatur

Membaca buku-buku, laporan, atau sumber kepustakaan lain yang berkaitan dengan pengecatan pada kapal.

\section{HASIL DAN PEMBAHASAN}

\section{A. Bahan dan Alat yang Diperlukan Untuk Pengecatan}

Pemilihan bahan dan alat juga sangat berpengaruh untuk proses pengecatan, karena setiap daerah atau bagian harus membutuhkan alat dan bahan yang berbeda untuk mendapatkan hasil yang maksimal dalam pengecatan permukaan kapal atau ponton. Untuk penggunaan bahan dan alat juga harus dilakukan dengan benar sesuai prosedur yang sudah ditetapkan untuk 
menghindari hal-hal yang dapatmerugikan banyak pihak dalam proses pengerjaan kapal maupun ponton tersebut.

Bahan

1. Pasir Blasting

Pasir silika (pasir kuarsa) adalah istilah industri yang digunakan untuk pasir atau batu pasir yang mudah terpilah dengan persentase butiran kuarsa (silica) yang sangat tinggi.

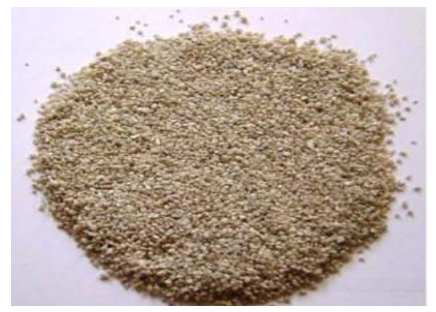

Gbr 5. Pasir silika (kuarsa)

2. Cat khusus kapal atau pontoon

Cat kapal pada umumnya sebutan untuk marine coating atau marine paint, dalam bahasa Indonesia dikenal dengan sebutan cat marine atau cat kapal, cat kapal termasuk deretan jenis cat yang berkelas dan berkualitas, karena cat kapal sendiri di fungsikan untuk melindungi bagian - bagian kapal agar terhindar dari korosi dalam jangka waktu yang cukup lama.

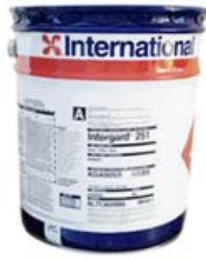

Gbr 6. Cat khusus kapal dan ponton

\section{Thinner}

Solvent / thinner adalah suatu bahan kimia yang berbentuk cairan dan mengandung satu atau beberapa jenis bahan kimia lain. Thinner / solvent biasa disebut juga dengan pelarut atau diluent yang berfungsi sebagai bahan pengisi atau filler.

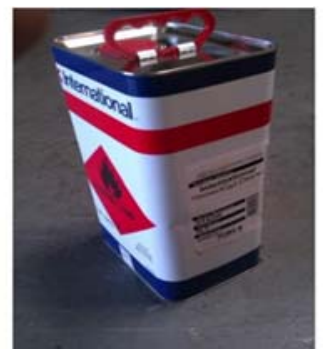

Gbr 7. Thinner
Peralatan yang digunakan dalam proses pengecatan diantaranya: sekrap baja, tangga besi, sikat kawat, air tawar, airless spray, sand pot, kompresor, selang cat , selang pasir sandblasting, nossle pasir sandblasting, air assisted spray gun, kunci-kunci pas dan ring, kuas atau roll, topeng, masker, sarung tangan

\section{B. Tahapan Proses Pengecatan}

Beberapa tahapan proses pengecatan yang harus dilakukan untuk menjaga kualitas hasil cat yang baik:

1. Pre-Inspection

Menginspeksi permukaan cat yang terkena

korosi maupun faktor-faktor penghambat lain dengan tujuan agar diperoleh perekatan secara maksimal ketika dilakukan proses painting.

\section{Surface Preparation}

Pada tahap ini dilakukan beberapa metode persiapan permukaan kapal yang akan di cat khususnya pada bagian bottom yang berada di bawah garis air:

a. Pembersihan terhadap tumbuhan/hewan laut

Pembersihan terhadap tumbuhan laut (fouling organisme) pada kapal Semar Sembilan Samarinda dilakukan dengan cara penyekrapan dengan tenaga manusia. Penyekrapan dilakukan dengan palu ketok dan chipping pada bagian yang ditempeli tumbuhan laut. Setelah selesai, pekerjaan dilanjutkan dengan pembersihan menggunakan sikatbaja (wire brush).

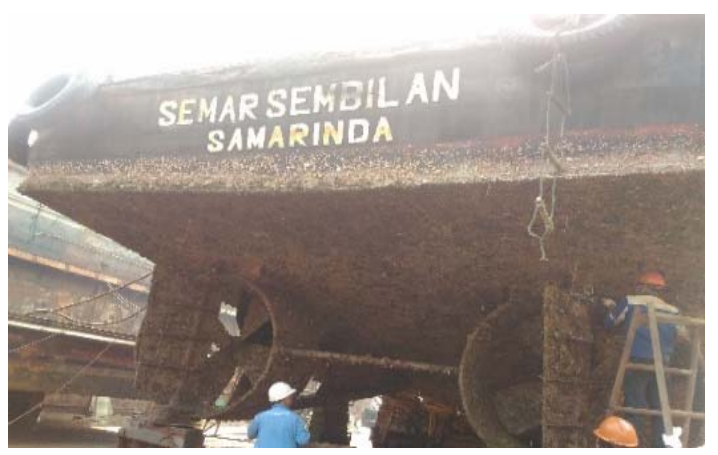

Gbr 7. Proses Pembersihan tumbuhan/hewan laut (fouling)

b. Pembersihan karat dan cat (blasting)

Proses blasting menggunakan bahan blasting pasirkuarsa dan udara yang ditembakkan melalui kompressor. Pasir kuarsa berdiameter 0,5-2 mm tersebut ditembakkan ke permukaan yang dikikis dengan tekanan sebesar $\pm 6 \mathrm{~kg} / \mathrm{mm}^{2}$. Setelah dinilai cukup permukaan kapal dapat dicuci dengan water jet untuk menghilangkan sisa tumbuhan laut dan menetralkan kadar garam air laut. Proses water jet dan sandblasting dapat dilakukan terbalik menurut jenis cat yang digunakan. 
Dalam proses sanblasting ini juga digunakan untuk membuat permukaan plat atau area yang ingin dicat nanti menjadi kasar sebagai fondasi coating system agar menempel dengan kuat ketika dilakukan pengecatan ulang.

Skema kerja blasting

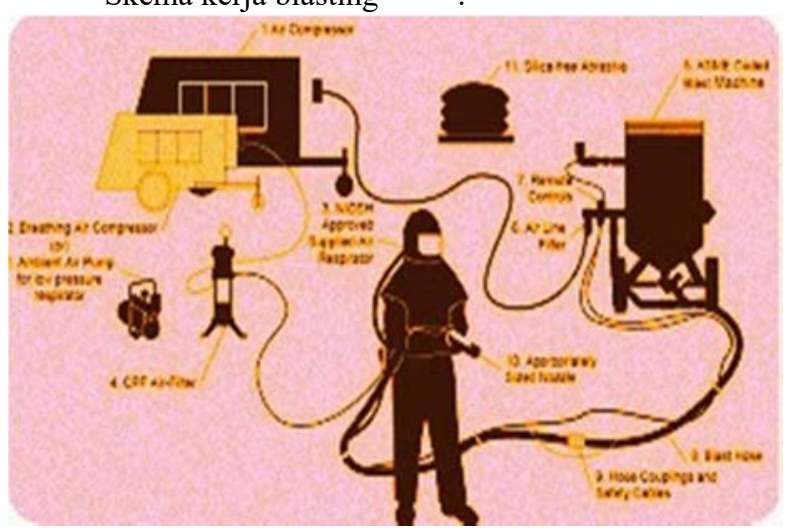

Gbr. 8. Cara kerja proses blasting [3]

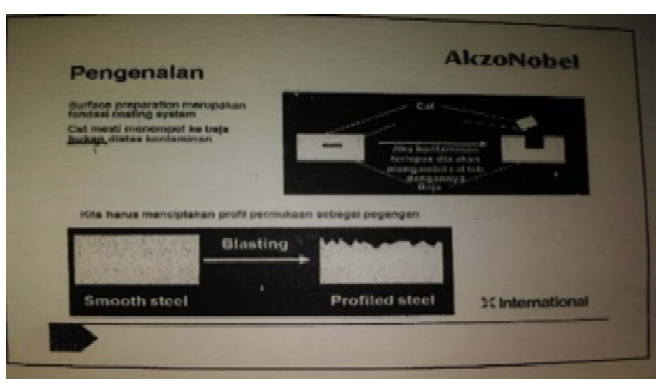

Gbr 9. Profil plat yang sudah terblasting

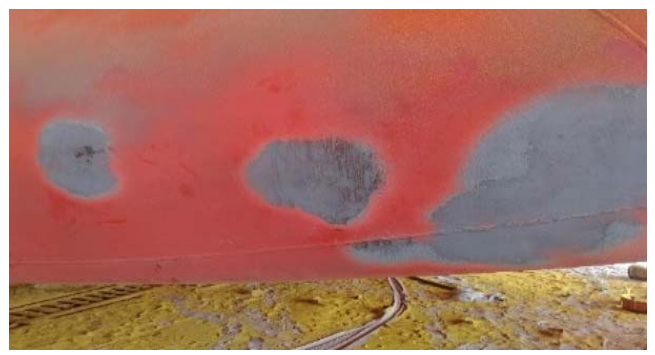

Gbr 10. Perbedaan area yang terkena sand blasting

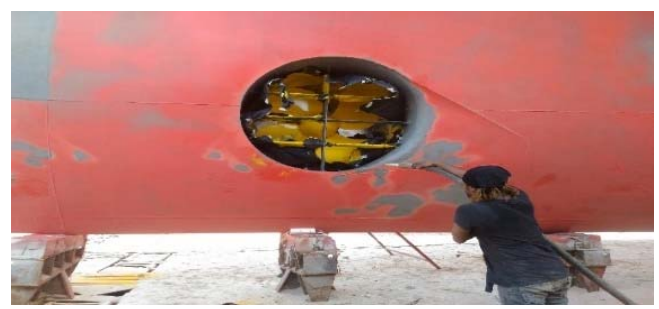

Gbr 11. Proses blasting pada area-area yang harus diciptaan profil baru untuk pengecatan ulang

\section{Paint Application}

Pada tahap ini, proses repainting (cat ulang) sudah boleh dilakukan. Namun, inspeksi hasil pengecatan wajib dilakukan setelah proses repainting selesai .

\section{Cara Pengecatan Pada Badan Kapal dan Ponton} pengedokan

Pengecatan dilakukan dengan metode konvensional seperti menggunakan kuas dan roll. Namun, pada bagian yang luas seperti bagian badan kapal. Pengecatan dilakukan dengan metode modern dengan menggunakan airless spray. Cara kerjanya dengan memberi tekanan tinggi untuk menyemprotkan cat pada bagian badan kapal atau ponton pendedokan.

Perbedaan dasar dari prinsip kerja konvesional air spray dan airless terdapat pada sistem atomisasi (pengkabutan). Dari sini maka kelebihan dan keterbatasan masing-masing alat bisa diketahui dan disesuaikan dengan kebutuhan.

\section{Conventional Air Spray}

Sebelumnya harus dipahami, bahwa udara bertekanan merupakan sumber tenaga yang besar sehingga mampu mengalirkan cat dari wadah ke tudung spray gun dan terjadi atomisasi pada tudung spray gun (air cap, kepala spray gun). Untuk dapat beratomisasi dengan baik, air spray membutuhkan tekanan angin sekitar 2 - 5 bar, selain itu ratio volume udara (cfm) dan cat harus di atur dengan baik untuk memastikan aplikasi pengecatan yang benar.

\section{Airless Spray}

Airless spray atau hydraulic spray painting, sesuai namanya, maka tidak ada udara bertekanan yang digunakan agar terjadi atomisasi. Atomisasinya terjadi karena adanya tekanan hidraulik pada cat yang ditransportasikan ke suatu celah yang sempit (nozzle atau tip) pada spray gun sehingga terjadi pengkabutan. Tekanan hydraulik pada airless ditimbulkan oleh pompa pengecatan. Airless membutuhkan tekanan hidraulik minimal $7400 \mathrm{psi}(51800 \mathrm{kPa})$ agar terjadi pengkabutan.

Dalam pengecatan tidak hanya dilakukan satu kali atau hanya 1 cat melainkan berlapis-lapis cat menyesuaikan kebutuhan kapal atau ponton. Karen cat mempunyai bermacam fungsi dan kegunaannya masingmasing seperti anti korosi, anti fouling, tahan panas dan lainya. Dan untuk ketebalan cat juga sudah ditentukan oleh standart internasional serta cat apa saja yang harus wajib digunakan pada kapal atau ponton pengedokan. 
Bagian-bagian airless spray:

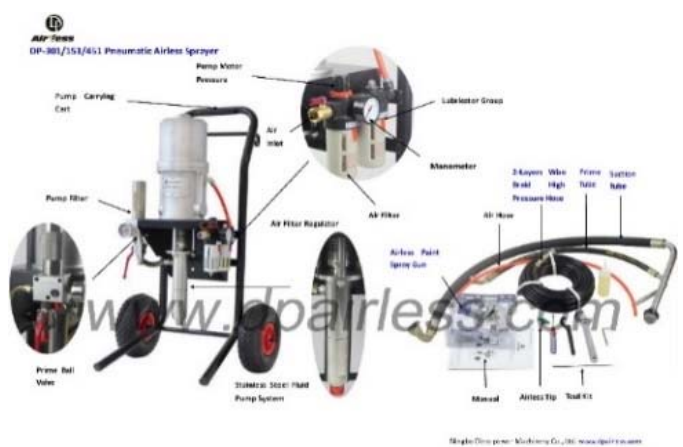

Gbr 12. Bagian airless spray [3]

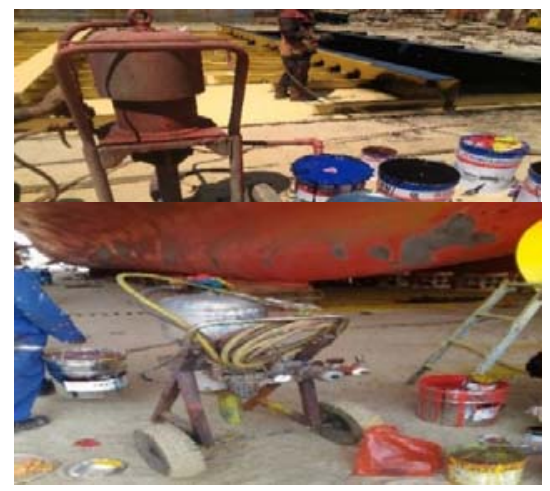

Gambar 13. Airlees spray yang digunakan untuk pengecatan.

Langkah-langkah penggunaan airless spray:

a. Siapkan cat dan alat lainnya

b. Pasang airless spray gun pada selang kemudian pasang selang katup keluar cat yang berada disamping motor

c. Hidupkan mesin airless spray

d. Bersihkan permukaan benda kerja yang ingin dicat menggunakan angin dan thinener untuk menghilangkan kotoran dan debu

e. Atur kombinasi cat yang akan digunakan untuk pengecatan

f. Masukan selang atau pipa hisap airless spray kedalam cat

g. Buka katup keluar dengan mengesuaikan tekanan hydraulik yang diinginkan agar membentuk kabut atau tidak

h. Sprotkan atau tembakan cat kepermukaan yang sudah ditargetkan dengan gerakan dan ketebalan yang sudah ditentukan

i. Jika sudah tutup katup dan bersihkan spray gun agar terjaga untuk keawetannya

j. Matikan airless spray dan lepas semua selang

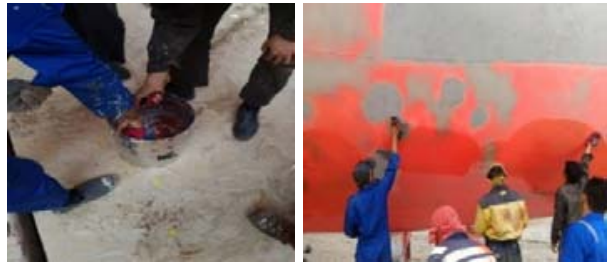

Gbr 14. Pembersihan permukaan yang ingin dicat ulang menggunakan thinner
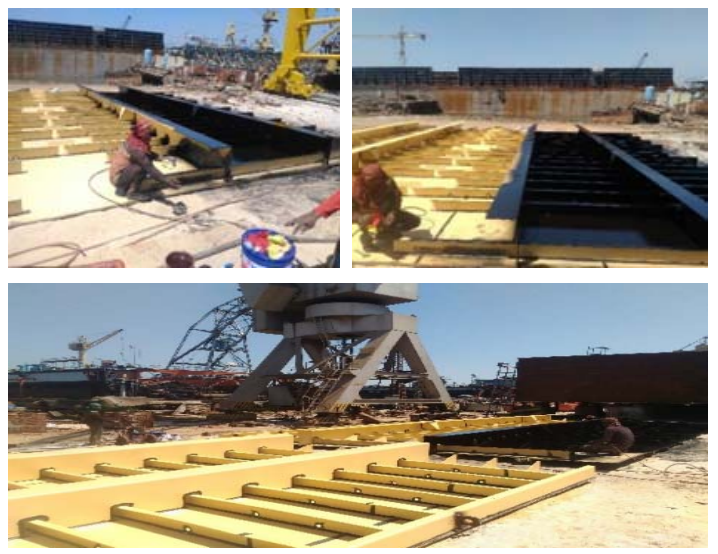

Gbr 15. Proses pengecatan menggunakan airless spray pada tutup ponton.

Dibawah ini merupakan hasil dari pengecatan tutup ponton yang mana dalam pengecatan tersebut menggunakan lebih dari 1 cat, dan dibedakan dengan 2 warna agar dalam pengukuran ketabalan cat mendapatkan hasil yang akurat untuk keseimbangan ketebalan kedua cat agar tidak berlebih dalam penggunaan cat dan memakan lebih banyak biaya.

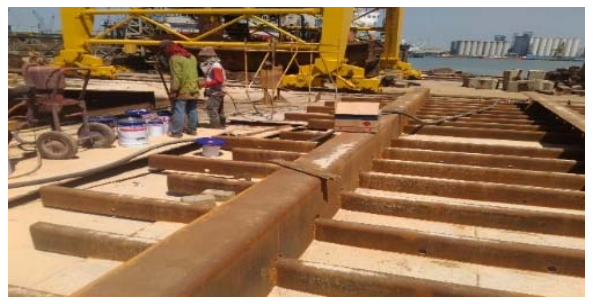

Gbr 16. Warna dasar dari tutup ponton setelah disand blasting

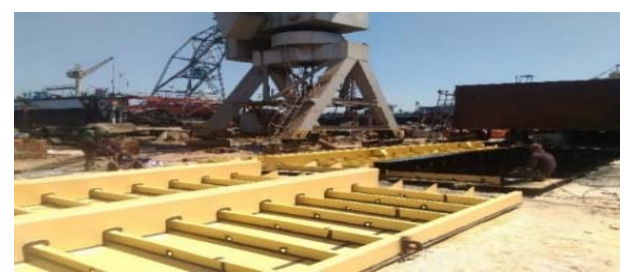

Gbr 17. Warna buff (kuning kecoklatan) merupakan cat anti karat 


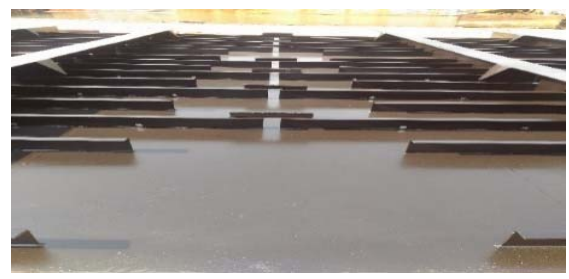

Gbr 18. Warna black (hitam) merupakan cat anti fouling atau hewan laut.

Faktor yang harus diperhatikan dalam pengecatan :

1) Cat tidak boleh diaplikasikan dalam kondisi :

a) Dibawah $5^{\circ} \mathrm{C}-$ kecuali menggunakan low temperatur cure paints

b) Diatas $35^{\circ} \mathrm{C}$ - dry overspray

c) Kondisi yang sangat berangin - over spay yang besar

d) Permukaan basah (rain,snow, ice, fog, condensation)

2) Pemeriksaan kondisi :

a) Ukur dan catat pembacaan wet dan dry bulp temperatur dari "whirling hygrometer"

b) Hitung "relative humidity" (RH) dan dew point

c) Ukur suhu permukaan dengan digital thermometer dikapal yang akan dicat

d) Ijinkan pengecatan jika suhu adalah $3^{\circ} \mathrm{C}$ atau lebih diatas dew point

\section{KESIMPULAN}

Proses sandblasting merupakan proses dimana untuk membuat profil permukaan agar berbentuk kasar dan mampu menjadi daya rekat yang kuat pada saat pengecatan. Dan Proses coating adalah proses pengecatan untuk melapisan permukaan dari berbagai macam gangguan luar seperti korosi, fouling, dan lainnya yang mampu mengurangi daya tahan logam permukaan pada kapal atau ponton. Keuntungan yang didapat dari proses sandblasting dan coating adalah hasil repair yang didapat lebih maksimal dan berkualitas, dibandingkan hanya melakukan proses pengecatan secara biasa serta biaya yang mampu di minimaliskan agar tidak terjadinya pembengkakan karena proses yang terbuang sia-sia dan waktunya juga

\section{REFERENSI}

[1] Fakultas Teknik Kelautan. 1978. "Diklat Konstruksi Kapal Baja Jilid II". Jakarta: Departemen Pendidikan dan Kebudayaan, Direktorat Jenderal Pendidikan Dasar dan Menengah

[2] Kusna, Indra Djaya. 2008. "Teknik Konstruksi Kapal Baja Jilid II". Jakarta : Departemen Pendidikan dan Kebudayaan, Direktorat Jenderal Pendidikan Dasar dan Menengah.

[3] Khodijah, Siti. 2014. Prosedur Untuk Pengerjaan Kapal Lengkap. Diakses Tanggal 25 Oktober 2017 Dari https://www.Scrib.Geologinesia.com/2014/Standart International Working Marine.

[4] Sutrisno Ahmad. 2013. Pengertian Kapal dan Bagian-Bagiannya. Diakses Tanggal 12 September 2017 Dari :
https://www.Kapal.Mania.com/2013/Pengertian Kapal dan BagianBagiannya.

[5] S. Djatmiko, Soedijono, Soedarsono. 1983. "Teknik Galangan Kapal dan Dock Jilid I dan Jilid II". Jakarta: Departemen Pendidikan dan Kebudayaan, Direktorat Jenderal Pendidikan Dasar dan Menengah

[6] Sofi Moch., dkk. 2008. Teknik Konstruksi Kapal Baja. Jakarta: Indra kusna djaya.

[7] Soegiono. 2006. Kamus Teknik Perkapalan Edisi Keempat. Surabaya (ID): Airlangga University Press.

[8] Windyadari Aulia, Ahmad FZ, Sarwoko. 2014. Studi Perbandingan Metode Pelapisan (Coating) pada Ruang Muat Berbasis Regulasi IMO; Jurnal Teknik Vol. 34 No. 3 ISSN 0852-1697; Semarang. 